\title{
Thomas Aquinas and the Voluntarists
}

\section{JEFFREY HAUSE}

\author{
St. John's Seminary College
}

There is at least some agreement among contemporary readers about Thomas Aquinas's action theory. ${ }^{1}$ On Aquinas's view, the rational part of the soul contains two faculties: a cognitive power-the intellect-and an appetitive power-the will. The will's formal object is the good. Consequently, whatever the will wills must be good or, more accurately, judged good by the intellect, which is the faculty that presents objects to the will. One cannot, then, will evil for evil's sake. Furthermore, Aquinas contends that, in every human action, the human being intends what it takes to be its ultimate end. Hence, every action must be at least apparently conducive to that ultimate end: it must be not only good but suitable.

Although this basic view is controversial-as it has been since Aquinas's time- - there is no doubt that it accurately represents Aquinas's thought. However, when commentators elaborate on this basic view, their interpretations begin to diverge sharply, and never more sharply than when they try to explain the relation-

I would like to thank Bob Pasnau and Norman Kretzmann for their helpful comments.

1. One of the many issues commentators disagree about is whether Aquinas significantly changes his account of human action over the course of his career. See, for instance, Odon Lottin, Psychologie et Morale aux XIIe et XIIIe siècles, 6 vols. (Gemblouz: Duculot, 1942-1960). Rosemary Zita Laurer questions Lottin's findings in "St. Thomas's Theory of Intellectual Causality in Election," New Scholasticism 28 (1954): 299-319; and Lottin replies in "La preuve de la liberté humaine chez saint Thomas d'Aquin," Recherches de Théologie Ancienne et Médiévale 23 (1956): 323-30. George P. Klubertanz, S.J. defends Lottin in "The Root of Freedom in St. Thomas' Later Works," Gregorianum 42 (1961): 701-24. Two dissertations take up the issues: A. B. Wingell, "The Relationship of Intellect and Will in the Human Act According to St. Thomas Aquinas" (University of Toronto Ph.D. diss., 1966) and David M. Gallagher, "Thomas Aquinas on the Causes of Human Choice" (Catholic University of America Ph.D. diss., 1988), who argues that Aquinas did not change his views substantially.

I will, therefore, limit my investigation to a group of works which, scholars agree, present substantially the same account of human action and the will's contribution to it: $D e$ malo (DM), De virtutibus in communi (DVC), Sententia super Peri hermeneias (IPH), and the IIa Pars of the Summa theologiae (ST). These late works contain Aquinas's fullest, most mature presentation of action theory. Scholars who conclude that Aquinas did change his action theory over time tend to find that these later works offer a more voluntarist, or more explicitly voluntarist, action theory. If I can show that Aquinas does not propound a voluntarist account in these later works, then I will have done most of the work needed to show that Aquinas never propounded a voluntarist action theory. 
ship between the intellect and the will. It is this relationship that I explore in this essay. In particular, I address the question: To what extent is Aquinas a voluntarist?

Generally, voluntarism is contrasted with intellectualism. "Voluntarism" in its widest sense refers to any view that asserts the will's superiority over the soul's other powers, in particular, the intellect. In this paper, I use the word more narrowly: an account of human action is voluntarist to the extent that the will, and not any other power, controls its own activities. Likewise, an account of human action is intellectualist to the extent that the will's activities are under the intellect's control.

Contemporary readers of Aquinas offer diverse answers to the question of Aquinas's voluntarism. Alan Donagan, T. H. Irwin, and Daniel Westberg take Aquinas to be an intellectualist. ${ }^{2}$ David Gallagher, along with Eleonore Stump and Norman Kretzmann, find a robust voluntarism in Aquinas. ${ }^{3}$ Other scholars, like John Finnis and Bonnie Kent, find voluntarist elements in Aquinas's action theory. ${ }^{4}$ Furthermore, those who take Aquinas to be, to whatever extent, a voluntarist disagree with one another about both the extent and characteristics of Aquinas's voluntarism. What, exactly, are the will's voluntaristic capacities and how are they exercised?

In my view, however, the debates among the voluntarist interpreters are all moot because Aquinas is not a voluntarist at all; he is a thoroughgoing intellectualist. On Aquinas's view, the will cannot, by any innate capacity, direct the intellect's attention, keep the intellect from issuing judgments about what one ought to do, or keep itself from willing what the intellect has determined one ought to do. Nor can it select one from among a variety of alternatives unless the intellect has first settled on that one as the alternative to be pursued. Which, if any, of a set of objects the will wills, and whether it wills anything or nothing at all, depends not on any voluntaristic capacity of the will, but on how the intellect judges the object in question. My goal, then, is to defend this intellectualist interpretation as the one Aquinas intended and to show how he integrates it into his fuller account of moral responsibility. But first I will explain why so many interpreters have found the voluntarist reading so appealing.

2. Alan Donagan, Choice: The Essential Element in Human Action (London: Routledge \& Kegan Paul, 1987); T. H. Irwin, "The Scope of Deliberation: A Conflict in Aquinas," in Review of Metaphysics 44 (1990): 21-42; Daniel Westberg, Right Practical Reason (New York: Oxford University Press, 1994). Westberg, using the words "voluntarism" and "intellectualism" in the broad sense, sensibly claims Aquinas is neither a voluntarist nor an intellectualist. However, he clearly takes Aquinas to be an intellectualist in the narrow sense of "intellectualism."

3. David Gallagher, "Free Choice and Free Judgment in Thomas Aquinas," in Archiv für Geschichte der Philosophie 76 (1994): 247-77; Eleonore Stump and Norman Kretzmann, "Absolute Simplicity," in Faith and Philosophy 2 (1985): 353-82.

4. John Finnis, "Object and Intention in Moral Judgments according to Aquinas," in The Thomist 55 1991: 1-27; Bonnie Kent, Virtues of the Will: The Transformation of Ethics in the Late Thirteenth Century (Washington, D.C.: The Catholic University of America Press, 1995). 


\section{VOLUNTARISM, DETERMINISM, AND INDETERMINISM}

One can find the most convincing evidence that Aquinas is a voluntarist in his remarks on human action. But before exploring that evidence, I will discuss a less plausible reason for thinking Aquinas a voluntarist. One might think

(1) Any non-voluntarist theory of human action that Aquinas might subscribe to entails determinism.

But Aquinas maintains that

(2) If determinism is true, human beings are not responsible for their actions.

In addition, he argues that

(3) Human beings are responsible for their actions.

Therefore, to be consistent, Aquinas must hold

(4) Human actions are not determined.

and

(5) A non-voluntarist theory of human action cannot be correct.

David Gallagher offers a version of this argument. According to Gallagher, an intellectualist action theory commits one to the view that one has no control over one's judgment. ${ }^{5}$ Unless Aquinas accepts voluntarism of a very strong sort, he must say that we have no control over how things appear to us; and since how things appear to us determines what we will, any theory short of a robust voluntarism implies that we have no control over our own doings. The will must govern how one sees an object as well as which objects one sees. Otherwise, we will not be free and responsible for our acts. ${ }^{6}$

One might challenge the first two premises of this argument. First, it is simply false to assume, as the first premise does, that a non-voluntarist theory rules out indeterminism. Aquinas might hold, for instance, that the will's activities are determined by the intellect, but deny the argument's assumption that the intellect acts deterministically. ${ }^{7}$

One might object to the argument's second premise as well. While it is true that Aquinas argues in several works against causal determinism precisely because

5. Gallagher, "Free Choice," p. 275.

6. Gallagher, "Free Choice," p. 267.

7. In conversation, Paul Hoffman made this proposal. 
it is incompatible with free choice and moral responsibility, it is not clear that he objects to every sort of causal determinism. Consider the argument against determinism he most frequently appeals to, one that has its source in Aristotle's $D e$ interpretatione IX. If our acts are all necessitated, then "deliberation, exhortation, precept and punishment, and praise and blame, which moral philosophy is concerned with, are destroyed." 8 There would be "no use for persuasion, or for threat, or punishment or reward, by which human beings are attracted to goods and drawn back from evils." "9 Apparently, the sort of determinism Aquinas objects to here is determinism that would render human beings unresponsive to reasons. If all our acts were necessitated, Aquinas implies, then no reasons offered to us would change our behavior. Hence, any plan to change a person's behavior by offering him reasons for acting or not acting (for example, by offering advice, or threatening punishment) is bound to fail.

Aquinas can well admit that this sort of causal determinism is incompatible with free choice without being an incompatibilist about free choice and every sort of causal determinism. Suppose, for instance, that the will's activity is determined by the intellect; and suppose that the intellect's activity, including its practical judgment, is in turn causally determined. To say that one's judgments are causally determined is not to deny that one arrives at them by rational reflection on the ends to be pursued, weighing of alternative courses of action, and the taking of counsel. A causally determined agent may be rationally reflective and responsive to reasons.

My purpose is not to offer conclusive reasons for taking Aquinas to be a compatibilist-determining Aquinas's views on this issue requires a separate study. ${ }^{10}$ I have tried to show only that it is far from obvious that he is an incompatibilist, as so many interpreters simply assume. Nor can we conclude from the fact that Aquinas argues against certain causal deterministic theses that he finds all of them false or threatening to moral responsibility. If one wishes, then, to argue that Aquinas is a voluntarist by relying on the premise that he is an incompatibilist about free choice and causal determinism, one must first offer a defense of that premise. Of course, as I have argued, even if it turns out that Aquinas is an incompatibilist, it will still not follow that he is a voluntarist.

8. DM 6c.

9. IPH lect. 14 n.5; cf. Ia 19.8 sc, 83.lc.

10. There is a need for good studies of Aquinas on causation and necessitation. No one contests that Aquinas's accounts of these subjects are importantly different from those offered by twentieth-century philosophers. In fact, they are importantly different from accounts offered by philosophers writing in the closing years of the thirteenth century. Further studies might show that Aquinas's metaphysics is, on these issues, so different from ours (or even from his successors') that we cannot properly categorize him as a determinist or indeterminist, compatibilist or incompatibilist. Alternatively, we might find that Aquinas did not address these issues fully enough or clearly enough for us to determine his views. My central argument does not depend on any particular answer to these questions. 


\section{VOLUNTARIST READINGS}

Even if Aquinas does think that certain forms of causal determinism are compatible with moral responsibility, he might nevertheless find that a voluntaristic action theory is more plausible than the competing alternatives. If he does in fact think that some version of voluntarism is the case, we should find evidence of this commitment in his detailed discussions of human action, as well as in his remarks about the relation between the will and passion, habit, and sin.

Commentators have generally found the most evidence for voluntarism in the First Part of the Second Part of the Summa theologiae. In that work, Aquinas maintains that the intellect moves the will only as a formal cause: When the will desires something the intellect presents to it, the intellect provides the content of that desire. But only two things can be efficient causes of the will's activity: God and the will itself. Although God can move the will to desire a specific object, $\mathrm{He}$ generally does not. Rather, He is the efficient cause of the will's actions because He gives the will its general inclination to the good, and this inclination is the basis for all its desires. What moves the will to a specific object, then, is the will itself. In fact, the acts of willing and not willing are up to the will, which is in control of its own acts. On the basis of these claims, some commentators take Aquinas to affirm a voluntarism of exercise: The will has a voluntaristic capacity to exercise its act or not. No other power has this capacity; the will is unique among powers precisely because of this control. Even when presented with the highest good, the will might not elicit an act of desire.

Other commentators find that Aquinas asserts a voluntarism of specification, rather than, or in addition to, this voluntarism of exercise. On this view, the will, undetermined by any other powers, including the intellect, has the capacity to select from among alternative courses of action the intellect presents as good. The intellect evaluates the alternatives, but the choice of this one rather than that is up to the will. As Aquinas writes, "A human being can will and not will, act and not act. Furthermore, it can will this or that and do this or that." 11

In what follows, I explore each of these two voluntarist interpretations. Although, in my view, the second is more plausible than the first, I do not think that either can be well justified as a reading of Aquinas. ${ }^{12}$

\section{IIA. Voluntarism of Exercise}

According to Bonnie Kent, Aquinas propounds an action theory that is largely, but not solely, intellectualist. Kent writes that Aquinas

11. ST IaIIae 13.6c.

12. To avoid unnecessary confusions, I am assuming that the will is free from naturally acquired or divinely infused habits. I grant that a will informed by habits can influence one's vision of the end and deliberation about the means, but I argue below that this concession is not an admission of voluntarism. 
teaches that the will always remains free to will or not. If it cannot act against the final judgment of the intellect, the option of inaction still remains. Second, Aquinas holds that the final judgment of reason is not reached without the will's consent. While his conception of consent is not entirely clear, he apparently wants to allow for some contribution by the will to the final judgment about what should be done. The will cannot specify or determine the judgment, but it can at least veto various means presented by intellect as suitable to the end. ${ }^{13}$

Kent denies that Aquinas holds a voluntarism of specification, but contends that he does hold a voluntarism of exercise. The will may act voluntaristically at different points in the course of an action. First, the will may either will or remain inactive in the face of an alternative presented as good by the intellect-including the alternative which the intellect determines one ought to pursue. Second, the will may influence the deliberative process preceding the final judgment of what the agent should do. The intellect cannot reach its final practical judgment without the will's consent.

Furthermore, on Kent's interpretation, the will can veto various means that are suitable (that is, conducive to the agent's ends), eliminating them from further consideration before the intellect reaches its final practical judgment. It is not clear, however, what this veto power consists in. At the very least, she means that the will can remain inactive at this stage of an act, thereby not giving its consent to a suitable alternative. Because the will's consent to an alternative $\mathrm{A}$ is a necessary condition of the intellect's deciding that one ought to pursue A, this failure to consent will amount to a sort of "pocket veto."

However, I cannot find adequate evidence for attributing this voluntarism of exercise to Aquinas. Kent cites Question 15 of the IaIlae, in particular, articles 3 and 4.14 In that Question, Aquinas does maintain that some acts of consent precede one's final judgment of what one ought to do. However, even if consent is a necessary condition of the intellect's making its final judgment, nothing follows from this regarding Aquinas's commitment to either voluntarism or intellectualism. If whether the will consents, and what it consents to, are determined by the intellect's judgments, then this view is quite compatible with a thoroughgoing intellectualism.

Kent also cites IaIIae 10.2c in defense of her interpretation. ${ }^{15}$ There, Aquinas writes that the will, when presented with the perfect good, cannot will an alternative; yet it is possible that it simply not will at all (and, a fortiori, that it not will anything at all when presented with a limited good). However, these claims too are equally compatible with an intellectualist interpretation. Aquinas is not asserting that the will can remain inactive after the intellect has made its final judgment about what the agent should do. He is merely saying that it is possible that a will, 
presented with any good whatsoever, not will that good. An intellectualist might explain this possibility in various ways. For instance, one might not will the perfect good because one is still in the process of weighing alternatives-a process that can go on indefinitely. Moreover, one's considerations-or distractions - can lead to other trains of thought. If an agent thinks it a good idea to turn his or her attention elsewhere, then the agent will be able to put aside the consideration of any good whatsoever, including the perfect good. Hence, even if the intellect is considering the perfect good, it is not necessary that the agent will that good. ${ }^{16}$ The intellectualist, as well as the voluntarist, can explain the freedom an agent has over the exercise of the will's act.

In their 1985 article "Absolute Simplicity," Eleonore Stump and Norman Kretzmann offer a voluntaristic reading of Aquinas. Like Kent, they contend that the will can refrain from willing any object presented as good by intellect. However, according to Stump and Kretzmann this capacity to refrain from willing is only one of several voluntaristic capacities the will has. They maintain that

the self-directedness or freedom of the will considered as its partial independence from the intellect is manifested in three capacities: (1) to choose among alternatives presented as equally good, (2) to refrain from pursuing a subsidiary end presented as good, and (3) to direct the intellect's attention. ${ }^{17}$

I have already addressed the second of these capacities, and I will turn shortly to a discussion of the first. Let me now consider the third.

Aquinas does not explain the process of deliberation in as much detail as one might like. All commentators agree that when the will moves the intellect, it is as an efficient cause. For example, the will can move the intellect to deliberate, to stop deliberating, or to consider the matter from other points of view. What they do not agree on, however, is whether the will, in so moving the intellect, acts voluntaristically. Stump and Kretzmann contend that it does. On their view, the will does not simply move the intellect to do what the intellect has already decided on as a good and suitable course of action. Rather, the will can coerce the intellect, "compelling the intellect to attend to some things and to ignore others." This is one feature of the will's "self-directedness . . . considered as its partial independence from the intellect." 18

I suspect that Stump and Kretzmann describe this event as compulsion in

16. “ . . . the will is moved in two ways: (1) with respect to the exercise of its act; (2) with respect to the specification of its act, which is on the basis of its object. Therefore, in the first way, the will is moved necessarily by no object; for, of any object whatsoever, one is able not to think about it, and consequently one is able not to will it actually." [" . . voluntas movetur dupliciter: uno modo, quantum ad exercitium actus; alio modo quantum ad specificationem actus, quae est ex obiecto. Primo ergo modo voluntas a nullo obiecto necessitate movetur; potest enim aliquis de quocumque obiecto non cogitare, et per consequens neque actu velle istud."]

17. Stump and Kretzmann, "Free Choice," p. 362.

18. Stump and Kretzmann, "Free Choice," p. 362. 
order to emphasize the will's independence from the intellect. Even if the will does act voluntaristically, however, it is unclear that its moving the intellect in this way counts as compulsion. To compel something is to move it against its inclination. So, for instance, to hurl a stone upward is compulsion because a stone naturally seeks the center of the earth. Likewise, if I have decided that I do not want to swim, yet you push me into the pool, you have compelled me because you have moved me contrary to my rational, all-things-considered desire. ${ }^{19}$ However, to move the intellect to focus on certain objects or features of objects is hardly to move it against its natural inclination.

Even if Aquinas would not say that the will compels the intellect, as long as it has the independence from the intellect that Stump and Kretzmann attribute to it, then Aquinas will turn out to be a voluntarist. Stump and Kretzmann cite as evidence of this independence Aquinas's claim that it is the will, and not the intellect, that moves the soul's other powers as an efficient cause. But this claim supports voluntarism no more than intellectualism: Aquinas might think that the will necessarily desires what the intellect has decided on, even if the intellect does not move the will as an efficient cause. Nevertheless, one might think that DM 6 ad 15 provides adequate support for their view:

Not every cause brings about its effect necessarily, even if it is a sufficient cause, because a cause can be hindered. As a result, sometimes its effect does not follow (for instance, natural causes, which do not produce their effects necessarily, but for the most part, because in a few cases they are impeded). So then, that cause which makes the will will something need not do so necessarily, because it is possible that an obstacle be introduced through the will itself: either by removing the sort of consideration that leads one to willing, or by considering an alternative, namely, that that which is proposed as good in some respect is not good.20

One might well take this short reply to attribute to the will a partial independence from the intellect. True, the will can will only what the intellect presents to it as good, and in fact one is led to willing what one wills because of the way the intellect presents it. Nevertheless, there is no object such that the will is necessitated to will it; and the reason Aquinas offers appears to be a voluntaristic one:

19. If I do want to swim, your pushing me will still count as compulsion if I do not want to be pushed into the pool. If I do want to be pushed, then your action does not count as compulsion. See, for example, $S T$ Iallae $6.4 \mathrm{c}$ and ad 2 .

20. "... non omnis causa ex necessitate inducit effectum etiam si sit causa sufficiens, eo quod causa potest impediri ut quandoque effectum suam non consequatur, sicut causae naturales, quae non ex necessitate producunt suos effectus, sed ut in pluribus, quia in paucioribus impediuntur. Sic igitur illa causa quae facit voluntatem aliquid velle, non oportet quod ex necessitate hoc faciat, quia potest per ipsam voluntatem impedimentum praestari, vel removendo talem considerationem quae inducit eum ad volendum, vel considerando oppositum, scilicet quod hoc quod proponitur ut bonum secundum aliquid non est bonum." 
The will can will to reconsider, or not to consider, any object. By reconsidering it, one can attend to its defects, find it unattractive, and therefore lose one's inducement to willing it. One likewise loses one's inducement if one simply puts the object out of mind. In either case, it is "through the will itself" that one changes one's mind and, accordingly, controls one's behavior.

No doubt, Aquinas does maintain that the will can move the intellect to attend to some considerations and to ignore others. It seems implausible that the will would not influence the way one views alternatives and comes to decisions; and so it is a strength of Aquinas's theory that it takes into account this influence. However, this feature of his theory supports neither the voluntarist nor the intellectualist interpretation over the other, as each interpretation can equally well account for these phenomena. The voluntarist will maintain that the will, independently of the influence of intellect or passion, inclines the intellect to focus on some points and not on others. The intellectualist will contend that the will inclines the intellect to focus on some points and not on others, but not independently of the influence of the soul's other powers. Aquinas maintains that human beings quickly develop intellectual and volitional habits: ways of seeing, habits of selective attention, dispositions in turn connected to habits of valuing, of caring or not caring about certain objects of thought or action. The intellectualist can then agree with the voluntarist that the will sometimes exercises its influence on the intellect at certain stages in the deliberative process even if the intellect does not pass any judgment at that stage. Acts of will that might appear to be voluntaristic inclinations, because they appear to be divorced from any judgment of intellect, are on an intellectualist reading linked to previous judgments of intellect. The intellectualist view does not, in short, fail to explain the range of influence the will has over the intellect. Still, even if it did fail to account for these phenomena, that failure alone would not give us any reason not to ascribe the intellectualist view to Aquinas.

The textual evidence for voluntarism of exercise is weak, and the case the commentators make for voluntarism reflects this fact. Nowhere does Aquinas present us with any clear, unambiguous assertion of voluntarism, even in his lengthiest treatments of action theory. Nevertheless, commentators have been reluctant to rule out the voluntarist interpretation; for Aquinas peppers his work on human action with remarks, usually unelaborated, which seem to imply a commitment to voluntarism:

(A) ... it is in the will's power ... not to act and not to will, and, similarly, even not to consider.

(B) The will is in control of even its own act, and willing and not willing are up to it. This would not be so if it did not have it in its power to move itself to willing.

(C) There is another manner of causing proper to the will, which is in control of its own act... 
(D) An act is imputed to an agent in this case: when it is in his power, so that he has control over his act. This is so in the case of all voluntary actions, because one has control over one's act through one's will ...

(E) ... if some object which is good universally and in accordance with every consideration should be offered to the will, the will necessarily will aim at it, if it should will anything; for it will not be able to will an alternative. ${ }^{21}$

These scattered remarks are, in my view, the best evidence that Aquinas was a voluntarist. However, as I will argue below, Aquinas clearly commits himself to intellectualism. I do not, however, think that he is torn between the two views: He is consistently an intellectualist. Accordingly, after defending the intellectualist interpretation, I will explain why, although he is an intellectualist, Aquinas's remarks often appear to support voluntarism.

\section{IIB. Voluntarism of Specification}

On a second voluntarist reading, independent of but compatible with the first, the will, undetermined by any other power of the soul, selects from among various options presented by the intellect. John Finnis argues for one version of this interpretation. ${ }^{22}$ As he rightly notes, in a complete human action which culminates in choice, the deliberation of reason may yield several judgments. To whatever reason finds suitable, the will consents. So far, Finnis holds an intellectualist line. But the intellectualist goes on to say that reason draws a further conclusion about which option is preferable, and the will chooses that option. In contrast, Finnis insists that practical judgment does not settle the object of choice. Otherwise, practical reasoning and its decisions would play the role of choice. ${ }^{23}$ It is true that reason shapes alternatives; it yields several judgments about the choiceworthiness

21. (A) “... est in potestate voluntatis . . . non agere et non velle, similiter autem et non considerare" (ST IaIIae 6.7 ad 3).

(B) “. . . voluntas domina et sui actus, et in ipsa est velle et non velle. Quod non esset, si non haberet in potestate movere seipsam ad volendum" (ST Iallae 9.3sc; see also DP 3.7 ad 13).

(C) "Est autem alius modus causandi proprius voluntati, quae est domina sui actus . .. " (ST IaIIae 10.1 ad 1$)$.

(D) "Tunc autem actus imputatur agenti, quando est in potestate ipsius, ita quod habeat dominium sui actus. Hoc autem est in omnibus actibus voluntariis: quia per voluntatem homo dominium sui actus habet... " (ST IaIIae 21.2c).

(E) “. . . si proponatur aliquod obiectum voluntati quod sit universaliter bonum et secundum omnem considerationem, ex necessitate voluntas in illud tendet, si aliquid velit: non enim poterit velle oppositum" (ST IaIIae 10.2c).

22. Finnis, "Object and Intention." Other proponents include Stump and Kretzmann ("Absolute Simplicity") and David Gallagher ("Free Choice").

23. Finnis, "Object and Intention," p. 7. 
of alternatives. But "where practical reasoning is followed by choice, that reasoning must have 'left something open' to choice."24

This interpretation gains credibility from a discussion of choice and consent at 15.3 ad 3:

Choice adds over consent a kind of relation in respect of that to which something is preferred; and so after consent, there still remains choice. For it can happen that deliberation finds several routes to the end, to each of which a person consents, since each is acceptable; but from among the many acceptable things, a person prefers one [to the others] by (or: in) choosing (eligendo). 25

One natural reading of this passage is Finnis's - but only one. The passage is far too ambiguous to use as the cornerstone of a voluntarist interpretation. Aquinas does not say, unambiguously, that the will, without direction from practical reason, selects from among the options presented to it. One cannot argue that, because choice is an act of the will, and because it is by choosing that one makes the final selection, reason makes no directive to choose which the will then follows. ${ }^{26}$ Here, Aquinas is concerned with contrasting two acts of will-consent and choice-not with detailing every step of the process from consent to choice. One should not be surprised, then, if he does not mention deliberation and decision.

\section{INTELLECTUALISM}

How will an intellectualist interpreter read those passages in which Aquinas appears to attribute a unique capacity for self-control to the will? Aquinas states quite plainly that it is up to the will to act or not, to will this or that-including

24. Finnis, "Object and Intention," p. 5. Where the evidence might be used to support different views, philosophers typically interpret figures they admire as holding the view they themselves find most correct. Interestingly, Alan Donagan, who is himself a voluntarist of a sort, thinks that Aquinas is not. See chap. 8 of Choice ("Will and Intellect") and "Thomas Aquinas on Human Action," in The Cambridge History of Later Medieval Philosophy (Cambridge: Cambridge University Press, 1982): 642-54.

25. ". . . electio addit supra consensum quandam relationem respectu eius cui aliquid praeeligitur: et ideo post consensum, adhuc remanet electio. Potest enim contingere quod per consilium inveniantur plura ducentia ad finem, quorum dum quodlibet placet, in quodlibet eorum consentitur: sed ex multis quae placent, praeaccipimus unum eligendo."

26. One cannot rule out the possibility that he means to imply by his very use of the word "choice" that reason has issued such a directive. The act of choice is not purely an act of will. Aquinas writes: "The word "choice' implies something involving reason or intellect, and something involving will ..." (ST 13.1c). Although the act of choice is substantially an act of will, it also includes a contribution by reason: The will and intellect concur to produce the single act of choice. But at this point it would be question-begging to say this is what he means. After all, Finnis agrees that the intellect plays a role in choice. We need evidence to establish exactly what that role is. 
whether the intellect considers something or not. What he does not say, however, is that it is up to the will alone, or independently of the intellect, to determine its own activity. That Aquinas offers no unambiguous statement of voluntarism anywhere in his numerous treatments of the will and human action is striking.

It is all the more striking because Aquinas elsewhere implies or clearly states that human beings have control over their acts through both reason and will, not just through the will alone. I argue below that reason's role is not simply to make presentations and recommendations to the will. Reason's role is to evaluate goals and means and to make plans in accordance with its evaluations. The will does not then determine itself to choose between the plans favored by reason and others, or to choose those plans or not to act at all. The will always chooses in accordance with reason's decisions, and it always executes those decisions in accordance with reason's commands. But if that is Aquinas's considered view, why does he frequently attribute control to the will, with no mention of any contribution by reason? The intellectualist will reply: because speaking of the will's control is a useful shorthand for speaking of the human being's control. In the Treatise on Human Acts, where one finds these attributions of control to the will, Aquinas is concerned with whether the activities of the soul's various powers-including the intellect's activities - are voluntary, free, and in our control. Since it is the will that moves the soul's powers to perform their acts, Aquinas can conclude that the acts of these other powers are free and in our control if the will, which moves those powers, has control over its own act and therefore moves them freely. In attributing this control to the will, however, Aquinas does not mean to assert a version of voluntarism. Rather, he is assuming the direction of reason in deliberation prior to the will's moving the soul's powers to their acts. Hence, Aquinas can write:

... the will is said to have control over its act ... because the first cause does not act on the will in such a way that it determines it to one (activity) necessarily, as it does determine nature; and so the determination of (its) act is left in the power of reason and will. ${ }^{27}$

The DP is a work of Aquinas's middle period, so I do not want to rely on the content of this passage in my argument for Aquinas's intellectualism. Nevertheless, it offers good evidence that Aquinas uses language which sounds voluntaristic ("the will is said to have control over its act") to express views which are not voluntaristic at all. Unlike natural or animal appetites, the will is not determined to act in fixed or instinctive ways. The human being can, through deliberation, determine itself to will one alternative or another, or not to will at all. Aquinas captures this idea pithily, if misleadingly, by saying that the will has control over its act.

IaIIae $77.7 \mathrm{c}$ offers further confirmation of the hypothesis that passages

27. “. . . voluntas dicitur habere dominium sui actus ... quia causa prima non ita agit in voluntate ut eam de necessitate ad unum determinet sicut determinat naturam; et ideo determinatio actus relinquitur in potestate rationis et voluntatis" (DP 3.7 ad 13). 
attributing control to the will are simply shorthand for a more complex, intellectualist view. In the course of his investigation into passion as an exonerating factor, Aquinas first distinguishes the various ways in which an event can be voluntary:

On this issue, two things apparently require consideration. First, that something can be voluntary either in itself, as when the will is borne directly to it; or in its cause, when the will is borne to the cause and not to the effect, as is clear in the case of someone who gets drunk voluntarily, for on this basis what he does through drunkenness is imputed to him as voluntary. Second, that something is called voluntary directly or indirectly. Directly, that to which the will is borne, but indirectly, that which the will was able to prevent, but did not prevent. ${ }^{28}$

Here, Aquinas does not mention any role for reason; and one might take his claim about indirect, voluntary events to imply that it is up to the will alone to move itself to stop an event from happening or not. However, it would be a mistake to read the passage in this way. Aquinas is not offering a full account of voluntariness here. He is simply trying to distinguish the various ways in which an event can be voluntary. Aquinas can mark these distinctions without mentioning reason's role in voluntary action, and with characteristic economy of expression he does so.

However, when in the same article he addresses the problem of how one can control one's passions or one's behavior when one is under the influence of a passion, he offers this explanation:

But sometimes a passion is not so great that it totally cuts off the use of reason. And in that case reason can drive out passion by turning towards other considerations, or it can keep from pursuing its effect, because the members are not applied to a task except through reason's consent . . . 29

Since Aquinas is not simply asking what is voluntary, but how one exercises control over one's behavior, he can no longer use the shorthand of the first part of the article. One calms one's passions by turning one's attention away from the thoughts that stir up those passions; and Aquinas writes that it is reason that turns toward other thoughts and thereby drives out the passions. Otherwise, one can simply avoid doing what one's passions prompt one to do. The explanation

28. "Circa quod duo consideranda videntur. Primo quidem, quod aliquid potest esse voluntarium vel secundum se, sicut quando voluntas directe in ipsum fertur; vel secundum suam causam, quando voluntas fertur in causam et non in effectum, ut patet in eo qui voluntarie inebriatur; ex hoc enim quasi voluntarium ei imputatur quod per ebrietatem committit. Secundo considerandum est quod aliquid dicitur voluntarium directe vel indirecte: directe quidem, id in quod voluntas fertur; indirecte autem, illud quod voluntas potuit prohibere, sed non prohibet."

29. "Quandoque vero passio non est tanta quod totaliter intercipiat usum rationis. Et tunc ratio potest passionem excludere, divertendo ad alias cogitationes, vel impedire ne suum consequatur effectum, quia membra non applicantur operi nisi per consensum rationis ..." 
Aquinas offers for this ability is not that the will can voluntaristically select something else, but rather that reason does not permit doing it. If an agent A sins because of passion, the reason A is responsible is that A's reason could have driven out passion, not that A's will could have calmed the passion or halted the action.

We can find further confirmation of this reading in Aquinas's explicit commitment to intellectualism of specification. For example, at DVC 1.9c, Aquinas writes: " . . . because the appetitive power is disposed to either (alternative), it does not aim at one of them except insofar as reason determines it to that [alternative]." 30 Similarly, at IaIIae 9.6 ad 3: "But a human being determines himself by his reason to will this or that. . ." 31 These passages imply that the will, provided it is free from habits, has no more inclination to any one particular object than to any other. What determines its inclination is entirely up to reason.

What about the case Stump and Kretzmann discuss, in which one is confronted with alternatives that appear equally suitable? The voluntaristic capacity to choose between equally good alternatives is an extremely weak voluntarism, for in such a case the will does not incline to any alternative against reason's better judgment. Because this is the limiting case of one version of voluntarism of specification, it is an important test case. If Aquinas had any inclination to voluntarism of specification, it is reasonable to expect that he would reveal it in discussing this case. He raises the question at 13.6 obj. 3 :

If any two things are entirely equal, a human being is not moved more to one of them than to the other; for instance, a hungry person is not moved more to one dish than to another if the food is equally desirable and placed an equal distance from him on either side, as Plato says, indicating the explanation of the earth's rest in the center of the universe, as De Caelo II says. ${ }^{32}$

However, he gives an intellectualist reply:

If two things are proposed (to the will) which are equal in one respect, nothing prevents our considering in one of them some quality which makes it stand out, and (so nothing prevents) the will's being inclined to that one rather than to the other. ${ }^{33}$

Aquinas does not offer his readers a reply as detailed as they might like. Nevertheless, the thrust of his remarks is clear: Reason's determination of some point of superiority in one option over another is a necessary condition of the will's choosing.

30. "Quia ... vis appetitiva se habet ad utrumlibet, non tendit in unum nisi secundum quod a ratione determinatur in illud."

31. "Sed homo per rationem determinat se ad volendum hoc vel illud ..."

32. "... si aliqua duo sunt penitus aequalia, non magis movetur homo ad unum quam ad aliud: sicut famelicus, si habet cibum aequaliter appetibilem in diversis partibus, et secundum aequalem distantiam, non magis movetur ad unum quam ad alterum, ut Plato dixit, assignans rationem quietis terrae in medio, sicut dicitur in II de Caelo."

33. ". . . nihil prohibet, si aliqua duo aequalia proponantur secundum unam considerationem, quin circa alterum consideretur aliqua conditio per quam emineat, et magis flectatur voluntas in ipsum quam in aliud." 
One also has good reason to think that Aquinas rejects voluntarism of exercise. In any case, Aquinas does not need to appeal to voluntarism of exercise in order to explain control over exercise. Aquinas contends that one can see any created object as good or as lacking in good. Seen as good, the object can be willed; but seen as lacking in good, the object is undesirable or even worthy of nolition. Accordingly, to the extent that one can focus on different characteristics of an object, to the extent that one can view it from different perspectives, one has control over the exercise of the will's act. ${ }^{34}$

For this very reason, Aquinas finds it important to stress that one always has significant control over how one views an object. No created object, no matter how good, is perfect, and so any created object can be seen as lacking and therefore undesirable. ${ }^{35}$ Nor can one's habits necessitate one to see an object in a certain way. The vicious person is not totally corrupt and can make some accurate value judgments. Furthermore, the virtuous person need not use virtue. ${ }^{36}$ Even if there is an object that one cannot help but view as perfect, one does not necessarily will it. After all, one can put it out of mind or keep oneself from considering it in the first place. ${ }^{37}$ Through deliberation, by considering an object from different perspectives and by weighing alternatives, one has control over the exercise of the will. This is precisely the view Aquinas articulates in IaIlae $109.2 \mathrm{ad}$, where he attributes control over one's acts, including acts of will, to reason: "A human being has control over his acts, over both willing and not willing, because of reason's deliberation, which can be shifted to one respect or another"'38

Of course, a voluntarist might wonder whether the way reason sees an object is due to a voluntaristic act of will. This suggestion, however, is pure speculation. Furthermore, if Aquinas had held such a view, one would have expected him to express it, for instance, at IaIIae 77.7c, where he offers an explanation of how one controls one's behavior. Instead, however, he attributes this control to reason and not to a voluntaristic act of the will.

\section{CONCLUDING WORRIES}

In my view, Aquinas offers an account of human action and responsibility that one should take seriously. Renewed interest in this part of Aquinas's philosophy, and

34. ST IaIIae 10.2c.

35. ST IaIIae 10.2c.

36. For Aquinas's claim that habits do not exercise any necessitating influence over one's judgments, see $S T$ IaIIae 71.4c, 78.2c, DM 6 ad 24. He notes that one need not use one's habits at ST IaIIae 49.3sc, 50.5c, 52.3c, 63.2 ad 2, (notably) 71.4c, 78.2c. For an explanation of this odd claim, see Jeffrey Hause, "Thomas Aquinas on the Will and Moral Responsibility" (Cornell University Ph.D. diss. 1995), pp. 90-113.

37. ST IaIIae 10.2c, DM 6c.

38. " . . . homo est dominus suorum actuum, et volendi et non volendi, propter deliberationem rationis, quae potest flecti ad unam partem vel ad aliam.” Cf. DP 3.7 ad 13 . 
contemporary developments of views expounded by Aquinas, show that I am not alone in my judgment. Still, others might worry that in all this talk of intellect and will, the human being has been lost. ${ }^{39}$ Furthermore, one might worry that I have misrepresented Aquinas. Does not Aquinas contend that, strictly speaking, it is not the power that acts but the substance that underlies the power?

It is true that, strictly speaking, it is substances that act. Nevertheless, they act through their powers, and powers have their own natures determining the ways in which the substance can act and respond. It is not unreasonable, moreover, to think that the interplay of a human being's various faculties, each acting in accordance with its own nature, just is the human being acting. ${ }^{40}$ This contention is especially plausible if one accepts a psychology like Aquinas's, in which the human being's various faculties do not act independently of each other but cooperate and influence each other. ${ }^{41}$ One might still worry, however, that this resolution of the human being into its powers effectively dissolves the human being, and we are left with a quasi-mechanical system. It is this worry, I think, that motivates some of the voluntarist interpretations of Aquinas. It is no surprise, then, that these readings appear more like interpretations of Scotus, who felt these very misgivings so strongly.

39. As John Boler put the worry in his talk, "The Will as Power: Its Explanatory Function" (presented at Yale University, 26 Sept. 1996).

40. A possibility Boler raised, but did not necessarily endorse, in his talk "The Will as Power."

41. As Daniel Westberg frequently stresses in Right Practical Reason. 